\title{
The multi-annual carbon budget of a peat-covered catchment
}

\author{
F. Worrall ${ }^{\text {a,* }}$, T.P. Burt ${ }^{\text {b }}$, J.G. Rowson ${ }^{\text {a }}$, J. Warburton ${ }^{\text {b }}$, J.K. Adamson ${ }^{\mathrm{c}}$ \\ a Dept of Earth Sciences, Science Laboratories, University of Durham, South Road, Durham, DH1 3LE, UK \\ ${ }^{b}$ Dept of Geography, Science Laboratories, University of Durham, South Road, Durham, DH1 3LE, UK \\ c Environmental Change Network, Centre for Ecology \& Hydrology, University of Lancaster, Bailrigg, Lancaster, Cumbria, LA1 4YO, UK
}

\section{A R T I C L E I N F O}

\section{Article history:}

Received 11 July 2008

Received in revised form 19 February 2009

Accepted 3 March 2009

Available online 16 April 2009

\section{Keywords:}

DOC

POC

Primary productivity

Net ecosystem respiration

Methane

\begin{abstract}
A B S T R A C T
This study estimates the complete carbon budget of an $11.4 \mathrm{~km}^{2}$ peat-covered catchment in Northern England. The budget considers both fluvial and gaseous carbon fluxes and includes estimates of particulate organic carbon (POC); dissolved organic carbon (DOC); excess dissolved $\mathrm{CO}_{2}$; release of methane $\left(\mathrm{CH}_{4}\right)$; net ecosystem respiration of $\mathrm{CO}_{2}$; and uptake of $\mathrm{CO}_{2}$ by primary productivity. All components except $\mathrm{CH}_{4}$ were measured directly in the catchment and annual carbon budgets were calculated for the catchment between 1993 and 2005 using both extrapolation and interpolation methods. The study shows that: Over the 13 year study period the total carbon balance varied between a net sink of -20 to $-91 \mathrm{Mg} \mathrm{C} / \mathrm{km}^{2} / \mathrm{yr}$. The biggest component of this budget is the uptake of carbon by primary productivity $\left(-178 \mathrm{Mg} \mathrm{C} / \mathrm{km}^{2} / \mathrm{yr}\right)$ and in most years the second largest component is the loss of DOC from the peat profile $\left(+39 \mathrm{Mg} \mathrm{C} / \mathrm{km}^{2} / \mathrm{yr}\right)$. Direct exchanges of $\mathrm{C}$ with the atmosphere average $-89 \mathrm{Mg} \mathrm{C} / \mathrm{km}^{2} / \mathrm{yr}$ in the catchment. Extrapolating the general findings of the carbon budget across all UK peatlands results in an approximate carbon balance of $-1.2 \mathrm{Tg} \mathrm{C} /$ $\mathrm{yr}( \pm 0.4 \mathrm{Pg} \mathrm{C} / \mathrm{yr})$ which is larger than previously reported values. Carbon budgets should always be reported with a clear statement of the techniques used and errors involved as this is significant when comparing results across studies.
\end{abstract}

(c) 2009 Elsevier B.V. All rights reserved.

\section{Introduction}

Schimel (1995) showed that during the 1980s atmospheric $\mathrm{CO}_{2}$ increased by $3.2 \mathrm{Gt} \mathrm{C/yr}$, but fossil fuel burning contributed and estimated $5.5 \mathrm{Gt} \mathrm{C} / \mathrm{yr}$. This discrepancy is in part explained by the ability of the terrestrial biosphere to uptake additional carbon. For example, within the terrestrial biosphere the northern peatlands are the most important terrestrial carbon store, and Gorham (1991) has estimated that $20-30 \%$ of the global terrestrial carbon is held in $3 \%$ of its land area. The northern peatland carbon store is estimated to be approximately $4.5 \mathrm{Gt} \mathrm{C}$ and over the Holocene northern peatlands have accumulated carbon at an average rate of $0.96 \mathrm{Mt} \mathrm{C} / \mathrm{yr}$, making this ecosystem not only a substantial store but also a large potential sink of atmospheric carbon. Under a warming climate this vital store could potentially be converted from a net sink to a net source of atmospheric carbon. As air temperatures increase a number of effects could be expected: carbon degradation is accelerated leading to increased release of $\mathrm{CO}_{2}$ from soil respiration (e.g. McKenzie et al., 1998); increasing drought frequency and severity triggers activation of new enzymatic processes (Freeman et al., 2001); and increasing temperature and drier conditions lead to increasing drawdown of water tables (Christensen et al., 1998). Inter-annual comparisons of net ecosystem exchange show that during dry years a peatland can

\footnotetext{
* Corresponding author. Tel.: +44 191374 2535; fax: +44 1913742510.

E-mail address: fred.worrall@durham.ac.uk (F. Worrall).
}

change from a net sink of carbon to a net source (Alm et al., 1999; Griffs et al., 2000). However, these climatic effects could be accentuated by other factors including: changes in atmospheric deposition and land management. Furthermore, the presence of increased atmospheric $\mathrm{CO}_{2}$ could in itself lead to increased carbon loss from the stock of carbon stored in peats (e.g. Saarnio et al., 2003). Decreases in atmospheric deposition of sulphur have been associated with increased losses of dissolved organic carbon (DOC) (Evans et al., 2005; Clark et al., 2005). Increased N deposition would lead to increased litter production (Aerts et al., 1992), enhances the release of carbon from roots to the soil (Cortufo and Gorissen, 1997); favours the vascular plants over mosses (Heijmans et al., 2001) and may inhibit $\mathrm{CH}_{4}$ oxidation (Steudler et al., 1989). In addition, management practices in peatlands have not necessarily been conducive to carbon storage. For example, peat drainage lowers the average water table depth allowing greater depth of oxygen ingress which has been suggested to lead to increased soil $\mathrm{CO}_{2}$ respiration (Glenn et al., 1993; Funk et al., 1994; Bubier et al., 2003); increased flux of dissolved $\mathrm{CO}_{2}$ (Jones and Mulholland, 1998); and potentially, increase losses of DOC (Mitchell and McDonald, 1995). Hence peatlands are subject to a complex array of processes which influence the overall carbon balance. With mounting threats to these peatlands the understanding of the carbon budget dynamics becomes increasingly significant.

Carbon budgets of peatlands have in general been estimated by two types of method: dating of peat accumulation, and measuring carbon fluxes between the ecosystem and the atmosphere. Dating methods 
have typically used radiocarbon dating of peat profiles to give a rate of carbon accumulation (RCA). These RCA values have been reported fro a range of sites across northern peatlands, and rates of accumulation vary from a high of $88.6 \mathrm{gC} / \mathrm{m}^{2} / \mathrm{yr}$ (Tolonen and Turunen, 1996) to as low as $0.2 \mathrm{gC} / \mathrm{m}^{2} / \mathrm{yr}$ on Baffin Island (Schlesinger, 1990). There are recognised problems with this technique including: long-term anoxic decay in the catotelm (Clymo et al., 1998); reservoir effects (Kilian et al., 1995, 2000); poor estimates of peat bulk density; and short term changes in carbon accumulation will not be well represented (Hilbert et al., 2000). In order to resolve some of these issues the short-lived radioisotope ${ }^{210} \mathrm{~Pb}$ has been used (e.g. Turetsky et al., 2004). However, such techniques are only capable of measuring the accumulation of peat and typically can only be used to estimate the average rate of accumulation above a specific horizon. If the peatland was losing carbon during any period for which the accumulation was studied this will lead to lower estimates of accumulation rates that misrepresent the current carbon budget in that peatland.

The second main approach is to calculate present day carbon budgets based on estimating fluxes of carbon exchanges at the surface of the peatland. Typically, the flux is the net ecosystem exchange (NEE) of $\mathrm{CO}_{2}$ which is taken as the balance between respiration and primary productivity. Numerous studies have explored the controls of NEE in northern peatlands. For example, the link between NEE and photosynthetic active radition (PAR) (Frolking et al., 2002), temperature and water table (Bubier et al., 2003). Generally studies have shown that peatlands can be net sinks of up to $260 \mathrm{gC} / \mathrm{m}^{2} / \mathrm{yr}$ of $\mathrm{CO}_{2}$ (LaFleur et al., 2002). However, no flux study has measured all possible carbon release pathways at a single site; most studies focus on $\mathrm{CO}_{2}$ exchange and sometimes $\mathrm{CH}_{4}$ release. Furthermore no studies have included monitoring of both the gaseous and the fluvial carbon flux. Full characterisation of fluvial carbon release would include: DOC, particulate organic carbon (POC), dissolved inorganic carbon (DIC) and dissolved $\mathrm{CO}_{2}$ (Dawson et al., 2002). Frolking et al. (2002) in their model of a peatland carbon simulator do include DOC as well as $\mathrm{CO}_{2}$ and $\mathrm{CH}_{4}$ but no other release pathways. It might be considered that only direct atmospheric exchange of carbon is important and so loss of carbon via fluvial pathways need not be considered. However, fluvial fluxes do contribute to atmospheric carbon and the stability of peatlands is often closely coupled to fluvial carbon loss (Evans et al., 2006). If both fluvial and gaseous losses are being considered then it is a peat-covered catchment that must be considered and not just a peat soil. Worrall et al. (2003a) estimated the first carbon budget of a peatland that considered both fluvial and gases exchanges. On the basis of purely the surface exchange of carbon gases (primary productivity and net ecosystem respiration of $\mathrm{CO}_{2}$ and $\mathrm{CH}_{4}$ ) calculations suggested the study catchment would be a next sink of $48 \mathrm{Mg} \mathrm{C}$ / $\mathrm{km}^{2} / \mathrm{yr}$, but when fluvial losses are included the peatland is only a marginal sink of $14 \mathrm{Mg} \mathrm{C} / \mathrm{km}^{2} / \mathrm{yr}$. Furthermore, fluvial carbon pathways can exchange carbon with the atmosphere, for example, the dissolved $\mathrm{CO}_{2}$ concentration of waters leaving a peat profile are normally in excess of that which would be in equilibrium with the atmosphere such that streams in peat catchments would be sources of $\mathrm{CO}_{2}$ to the atmosphere (e.g. Hope et al., 2001). Furthermore, degradation of DOC and POC may occur in the fluvial system releasing $\mathrm{CO}_{2}$ to the atmosphere. For an $11.4 \mathrm{~km}^{2}$ peat-covered catchment in Northern England, Worrall et al. (2006a,b) have shown that DOC loss due to in-stream processes was equivalent to $32 \%$ loss of DOC export. At a larger scale if the same catchment is considered from headwaters to tidal limit (a catchment of $818 \mathrm{~km}^{2}$ ) the loss of DOC equates to more than the loss of $\mathrm{CH}_{4}$ from the catchment.

However, the estimated carbon budget proposed by Worrall et al. (2003a) had a number of limitations. Firstly, the study could not measure all the possible uptake and release pathways, it had to rely on estimates from measurements taken at other UK catchments and adjusts these for local hydroclimatic conditions. Secondly, the description of the inorganic carbon flux from the peat was inaccurate: the study calculated the loss of total inorganic carbon and subtracted the inputs of weathering from the underlying strata and then added the excess dissolved $\mathrm{CO}_{2}$ concentration as well. In understanding the loss of peat carbon only the calculation of the excess dissolved $\mathrm{CO}_{2}$ is necessary. Thirdly, for none of the fluvial flux components were the losses in-stream considered. Fourthly, the study of Worrall et al. (2003a) considered only one year indeed, Griffs et al. (2000) and Alm et al. (1999) have shown that the net ecosystem exchange of a peat bog can change from a net sink to a net source in dry years.

Therefore, the aim of this study is to construct the most complete carbon budget for the peat soils within a single catchment, for the soils of that catchment but the soils within that catchment. The study endeavours to include all carbon release pathways measured in one catchment, correct for fluvial losses so that carbon budget of the soils within the catchment is assessed and compare data for more than one year.

\section{Methodology and approach}

This study considers the following carbon uptake and release pathways: net ecosystem respiration of $\mathrm{CO}_{2}$ and $\mathrm{CH}_{4}$; primary production, dissolved $\mathrm{CO}_{2}$, dissolved organic carbon (DOC), particulate organic carbon (POC) and input of carbon from rainfall. This study assumes that particulate inorganic carbon and dissolved $\mathrm{CH}_{4}$ are negligible (Hope et al., 2001). All these uptake and release pathways were measured within this catchment except for $\mathrm{CH}_{4}$ fluxes.

\subsection{Study site}

Moor House and Upper Teesdale National Nature Reserve (NNR) is situated in the North Pennine upland region of the UK (Fig. 1). The Moor House NNR is a terrestrial and freshwater site which is part of the UK Environmental Change Network (ECN). The ECN collects various hydrological and water quality data from the Trout Beck catchment that lies within the Moor House NNR. The Trout Beck catchment occurs mainly above $450 \mathrm{~m}$ O.D. with the highest point being the summit of Cross Fell at 893 m O.D (National Grid Reference NY 756326, N54:41:18 W2:22:45). The underlying geology is a succession of Carboniferous limestones, sands and shales with intrusions of the doleritic whin sill (Johnson and Dunham, 1963). The solid geology is covered by glacial till and colluvial material whose poor drainage qualities facilitated the development of blanket peat during the Holocene. Blanket peat covers $90 \%$ of Trout Beck catchment (Evans et al., 1999). The vegetation of the reserve is dominated by Eriophorum sp. (cotton grass), Calluna vulgaris (heather) and Sphagnum sp. (moss). The mean annual temperature $(1931-2000)$ is $5.2{ }^{\circ} \mathrm{C}$; air frosts are recorded on over 100 days in a year (1991-2000, Holden, 2001). Mean annual precipitation (1953-1997) is $1953 \mathrm{~mm}$ (Burt et al., 1998). Any rainfall in the catchment produces a rapid runoff response: studies at Moor House have shown that the lag between peak rainfall intensity and peak flow can be as little as 30 min (Burt et al., 1998).

A flow gauging station is situated on the Trout Beck with discharge being recorded hourly. The catchment area above the Trout Beck gauging site is $11.4 \mathrm{~km}^{2}$. A meteorological station is situated within the catchment (Fig. 1) with hourly recording of rainfall by tipping bucket raingauge; the recording of air and soil temperature at $10 \mathrm{~cm}$ below the soil surface; and solar radiation. In addition, a network of five piezometers has been installed in the catchment and the depth to the water table is monitored every $15 \mathrm{~min}$ with levels having been calibrated weekly since October 1994.

Water samples were collected weekly from five stream sites, along with precipitation samples. Samples were also taken fortnightly from six soil solution samplers at two depths, 10 and $50 \mathrm{~cm}$, the former will be referred to as shallow soil water and the latter as deep soil water. This study focuses on the analysis of stream sampling records at the 


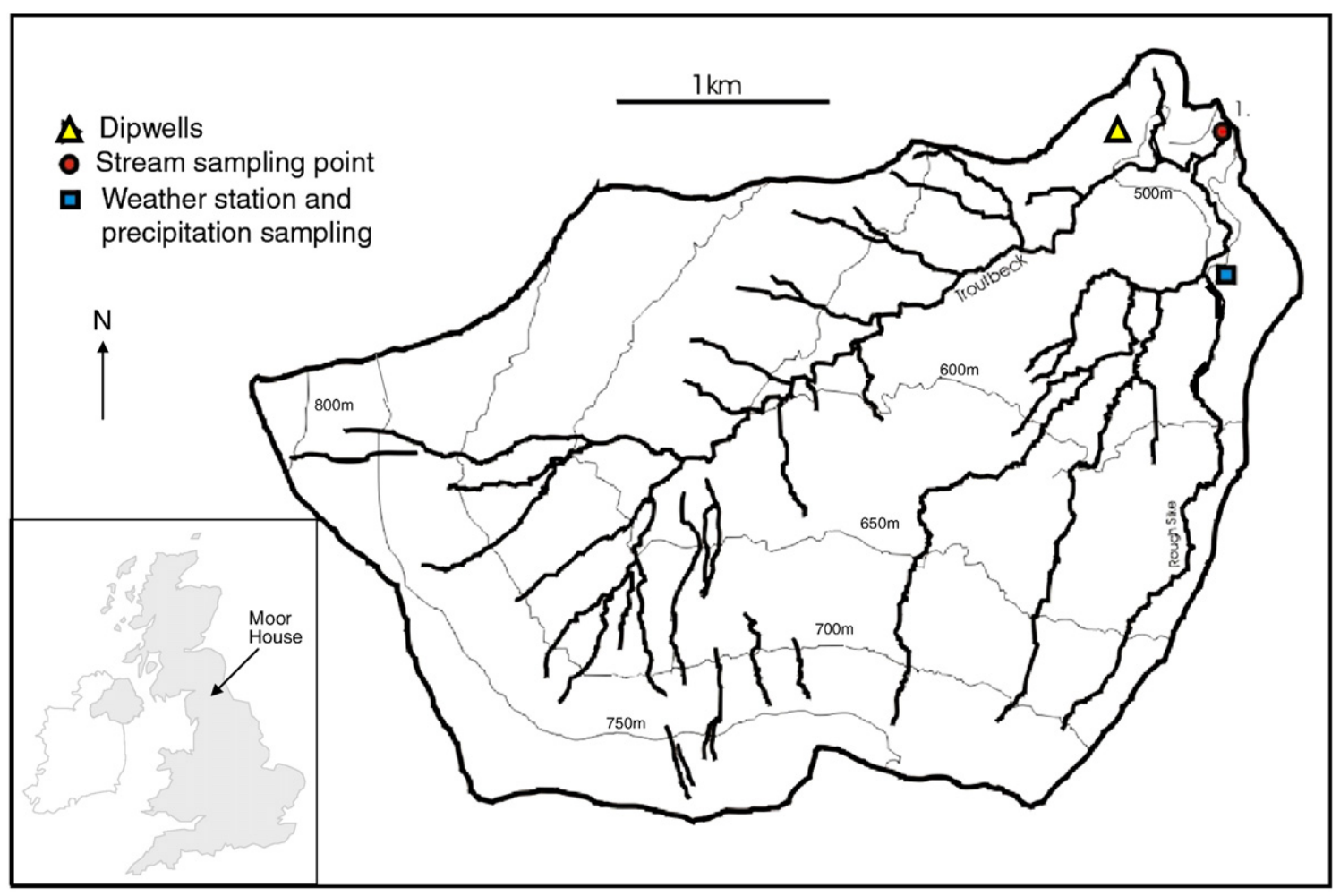

Fig. 1. The location of the Trout Beck study site, Northern England.

Trout Beck gauging station, Cottage Hill Sike (a first-order stream within the peat), soil water samples and precipitation samples (Fig. 1). Water samples were analysed for: conductivity, $\mathrm{pH}$, alkalinity, calcium, magnesium, potassium, sodium, iron, aluminium, chloride, sulphate, DOC, DOC absorbance at $400 \mathrm{~nm}$ and Total $\mathrm{N}$. The methods of analysis are detailed in Sykes and Lane (1996) and for soil water samples in Adamson et al. (2001).

\subsection{Budget calculation}

Calculation methods involve both interpolation and extrapolation techniques. A wide range of interpolation methods have been proposed (e.g. De Vries and Klavers, 1994; Littlewood, 1995). Littlewood et al. (1998) recommend the use of their "method 5" where data are relatively sparse but showed that the best estimation method could vary between determinands and between catchments with interpolation methods working best for those determinands where a strong seasonal component existed - they did not review data for any form of carbon. For the purpose of this study interpolation methods were used for $\mathrm{DOC}$ and dissolved $\mathrm{CO}_{2}$ where, a priori, a strong seasonal component would be expected (Naden and McDonald, 1989). This study, therefore, uses "method 5" of Littlewood et al. (1998):

Flux $=K \frac{\sum_{i=1}^{n}\left[C_{i} Q_{i}\right]}{\sum_{i=1}^{n} Q_{i}} Q_{T}$

where: $K=$ conversion factor allowing for period of sampling; $C_{i}=$ concentration of determinand in sample $\mathrm{i} ; Q_{\mathrm{i}}=$ instantaneous discharge at sampling time $i ; Q_{T}=$ mean river discharge over the period; and $n=$ number of samples.

For extrapolation methods calibration between the determinand and its most significant driver or drivers is required; and if the driver is known across the seasonal cycle then the annual flux may be calculated. For fluvial fluxes extrapolation methods work best where a good rating curve between concentration and flow can be found and so extrapolation methods were used for calculating the POC flux. Similar strong relationships can be found between environmental variables monitored in the catchment and primary productivity, net ecosystem respiration and methane.

\section{3. $\mathrm{DOC}$}

Monitoring by ECN includes weekly spot samples used for DOC concentration at the catchment outlet. Sampling of DOC means that a budget for DOC from the catchment can be calculated from 1993 to 2005. However, to properly estimate the loss of DOC from the peat soils of the catchment, it is necessary to consider losses and gains of DOC within the streams of the catchment. Worrall et al. (2006a,b) proposed two methods for calculating the loss of DOC from the peat soils for this same catchment, one based upon a two end-member mixing analysis and another based upon a principal component analysis. However, an alternative and a more conservative approach in this catchment is to consider the composition of the soil water. Worrall et al. (2003b) showed that for this catchment the source of the water could be described by three end members - two rainfall and one soil water end-members. This implies that the source of the DOC leaving the catchment is adequately described by the composition of the soil water. Therefore, the flux of DOC from the catchment will be assessed, firstly, on the basis of that concentration measured at the outlet of the Trout Beck catchment. Secondly, instead of just using the concentration of DOC at the catchment outlet, the concentration of DOC in the shallow soil water will be used in combination, assuming a three end-member mixing with rainfall, and using the flow through the catchment, i.e. the flow measured at the outlet of the Trout Beck catchment. This assumes that all the water flowing through the catchment has all come through the shallow peat and that the three end member approach is sufficient to explain for any dilution. This approach will probably be an overestimate as it assumes no additional dilution from groundwater. By using these two methods it is possible to assess the loss of DOC within the streams of the 
catchment, i.e. the flux of DOC at the catchment outlet would be expected to be lower than the DOC flux as calculated from the soil water concentrations. Therefore, for DOC this study is assessing the carbon budget of the peat soils within the catchment rather than the catchment as a whole.

\subsection{POC}

POC was estimated from storm samples, i.e. sampling triggered on the storm hydrograph as opposed to the baseflow, collected as part of a suspended sediment load monitoring programme undertaken in the Trout Beck catchment (Evans and Warburton, 2005). The sediment yield was estimated from a log-log rating curve relating discharge to suspended sediment concentration. A correction factor was applied to remove the bias introduced by back transforming the data (Ferguson, 1986). Suspended sediment flux measurements were converted to POC estimates based on the measurement of the carbon content of the collected suspended sediment. This measure of POC flux is not corrected for transformations within the stream network and so is a flux from the catchment as a whole and not from the peat soils of the catchment. It is not known what transformations occur in the stream network and so the flux from the peat soils of the catchment cannot be known and the whole catchment flux is the only estimate available.

\subsection{Dissolved $\mathrm{CO}_{2}$}

The excess dissolved $\mathrm{CO}_{2}$ concentration was calculated in the waters leaving the study catchment. Excess dissolved $\mathrm{CO}_{2}$ is defined as the amount of dissolved $\mathrm{CO}_{2}$ found in the water above that which would be expected to be present if the water were equilibrium with the atmosphere. The excess dissolved $\mathrm{CO}_{2}$ concentration was calculated using the method of Neal et al. (1998). The excess dissolved $\mathrm{CO}_{2}$ can be estimated given only the alkalinity and the $\mathrm{pH}$ of the water, but a better estimation can be made if the temperature and Ca concentration of the water are available as well so a complete speciation of the inorganic carbon can be achieved. ECN monitoring of the Trout Beck stream includes Ca, alkalinity and $\mathrm{pH}$ with stream temperature was calculated for the Trout Beck stream using the method of Crisp and Howson (1982). The excess dissolved $\mathrm{CO}_{2}$ concentration at the catchment outlet is, however, not the concentration leaving the peat soils of the catchment. In order to back calculate the excess dissolved $\mathrm{CO}_{2}$ concentration as water emerges from the peat soils of the catchment it is necessary to account for evasion of $\mathrm{CO}_{2}$ from the streams of the catchment and for in-stream production of $\mathrm{CO}_{2}$. The evasion rates were calculated using the thin film diffusion model (Liss and Slater, 1974) and on the basis of knowing the residence time of stream water within the catchment. The rating curve for the Trout Beck gauging station was used to estimate stream depth and, given the total stream length within the catchment it was assumed that the $\mathrm{CO}_{2}$ evaded the stream at the mid-length point. The in-stream production was estimated following the method of Worrall et al. (2005) based upon measurements of biochemical oxygen demand (BOD) across a range of low conditions within the catchment.

\subsection{Surface exchange of $\mathrm{CO}_{2}$}

The exchange of $\mathrm{CO}_{2}$ at the peat surface in the catchment is considered to be composed of two components - net ecosystem respiration and primary productivity.

The net ecosystem respiration directly from the soil surface was estimated by two different methods. A commonly used method is that proposed by Lloyd and Taylor (1994) who link net ecosystem respiration to soil temperature. This present study used the approach of Lloyd (2006) and Rowson (2007) that both identified depth to the water table as a significant factor in controlling net ecosystem respiration. The best-fit equation from the study of net ecosystem respiration data was:

$\log R=0.16 \log W_{D}-\frac{8252}{T}+26.0 r^{2}=0.64, n=385$.

(0.01) (0.00) (0.00) significance of coefficient

(0.04) (390) (1.4) standard error of coefficient

where $R=$ the flux of $\mathrm{CO}_{2}\left(\mathrm{~g} \mathrm{C} / \mathrm{m}^{2} / \mathrm{hr}\right)$, and $W_{\mathrm{D}}=$ the depth to the water table $(\mathrm{m}) ; T=$ air temperature $(\mathrm{K})$. The first row of figures in the brackets represents the probability that the coefficient is equal to zero, and the second row of figures in brackets represents the standard error in the coefficient. This has several advantages over the approach of Lloyd and Taylor (1994). Firstly, it is stated in terms of the air temperature rather than the soil temperature the former being more likely to be measured over longer periods within a catchment and thus enabling better extrapolation of the results. Second, it is adjusted for the size of aerobic zone in the peat profile. Allowing for the depth to the water table is a better approximation of the observations and results in a root mean square error (RMSE) of 0.14 which is lower than for the Lloyd and Taylor approach (RMSE of 0.159).

Calibration of Eq. (2) was achieved with net ecosystem respiration measurements from closed, dark chamber measurements of net ecosystem respiration using an Infra Red Gas Analyser (IRGA) (PP systems EGM-4, Hitchin, UK). The chamber also included an air temperature probe and measurements were taken on fixed collars adjacent to a piezometer where the depth to the water table was measured. The calibration took place with net ecosystem respiration being measured in four $15 \mathrm{~cm}$ diameter collars across a transect of $10 \mathrm{~m}$ where the vegetation in the collar was dominated by Calluna vulgaris - the dominant vegetation of the catchment as a whole. The chamber was applied to each collar in turn with each flux measurement taken between 2 and 5 min with an internal fan within the chamber being used to flush the chamber between measurements. Respiration measurements were made approximately every 2 weeks for 18 months with 384 measurements being taken in total. Measurements with the IRGA were calibrated by gas chromatography.

An alternative and independent approach to the estimation of the net ecosystem respiration is to consider the loss of dissolved $\mathrm{CO}_{2}$ as being indicative of the production of $\mathrm{CO}_{2}$ within the soil pore space, Jones and Mulholland (1998) have proposed a method for not only back tracking dissolved $\mathrm{CO}_{2}$ to the losses from the soil profile but also to estimate a catchment wide net ecosystem respiration. Worrall et al. (2005) have shown that the approach of Jones and Mulholland (1998) gives comparable results to those of extrapolation from soil temperature within a peat soil catchment. This present study calculates the excess dissolved $\mathrm{CO}_{2}$ concentration at emergence as described below. Taking this calculated excess dissolved $\mathrm{CO}_{2}$ at emergence and applies the method of Jones and Mulholland (1998) given the proportion of soil water in runoff estimated from the three end member approach (Worrall et al., 2003a) and the measurement of the depth to the water table within the catchment in order to calculate the net ecosystem respiration of $\mathrm{CO}_{2}$.

For primary productivity two methods were used. First, a common approach is to link primary productivity (PP) to photosynthetically active radiation (PAR), Bubier et al. (1998) have proposed a rectangular hyperbola model fit of the form:

$\mathrm{PP}=\left(\frac{\mathrm{GP}_{\max } \alpha \mathrm{PAR}}{\alpha \mathrm{PAR}+\mathrm{GP}_{\max }}\right)$.

Where $\alpha$ (alpha) = initial slope of the rectangular hyperbola (also called the apparent quantum yield and a conversion factor between units), $\mathrm{GP}_{\max }=\mathrm{NEE}$ asymptote $\left(\mathrm{g} \mathrm{C} / \mathrm{m}^{2} / \mathrm{hr}\right)$, and PAR = photosynthetically active radiation $\left(\mu \mathrm{mol} / \mathrm{m}^{2} / \mathrm{h}\right)$. This equation was calibrated for 
the site using the same closed chamber, IRGA approach as for the net ecosystem respiration, but in this case the chamber is used without a cover. The calibration of Eq. (3) took place at the same time as net ecosystem respiration measurements were made. The primary productivity is taken as the difference between the net ecosystem exchange (NEE) and the net ecosystem respiration. The NEE measurements were taken in four $15 \mathrm{~cm}$ diameter collars positioned across a $10 \mathrm{~m}$ transect containing a range of vegetation typical of the site. In total 384 NEE measurements were made over an 18 month period. Long term monitoring of PAR are not maintained for the site but records of 15-min PAR measured for 2004 were calibrated against solar radiation records for the study site maintained hourly. Where the best-fit calibration equation is:

PAR $=19.39+1.79 S r^{2}=0.82, n=8760$

where: $S=$ solar radiation $\left(W / \mathrm{m}^{2}\right)$; and PAR $=$ photosynthetically active radiation $\left(\mu \mathrm{mol} / \mathrm{m}^{2} / \mathrm{h}\right)$.

The second common approach to the estimation of primary productivity is to link productivity with water balance and actual evaporation:

$P=3000\left(1-e^{-9.695 \times 10^{-4}(A E T-20)}\right)$

where: $P=$ annual net primary productivity $\left(\mathrm{g} \mathrm{C} / \mathrm{m}^{2}\right)$; and AET $=$ annual actual evaporation ( $\mathrm{mm}$ ). Garnett (1998) has shown that there is a statistically significant link between actual evaporation and primary productivity at the study site and that Leith's model was appropriate.

\subsection{Rainfall carbon}

The annual DOC load to the catchment due to dry and wet deposition was calculated from DOC measurements in the precipitation samples collected as part of the ECN network and the measured volumes of rainfall. At Moor House, dry and wet deposition are included in the same precipitation samples, i.e. separate estimates of dry and wet deposition inputs of carbon cannot be made. It was assumed that: rainfall was at equilibrium with the atmosphere, i.e. contains no excess dissolved $\mathrm{CO}_{2}$; would contain negligible POC but would have acquired DOC in the atmosphere. When the DOC budget of a peat is considered only at the catchment outlet then some component of that measured DOC export does not come from the peat but a proportion comes in with the rainfall and so the rainwater DOC needs to be accounted for. However, if the direct loss of DOC from peat soils is assessed by considering the composition of shallow soil water, then it is not necessary to consider the rainfall inputs separately.

\subsection{Methane}

The only component of the carbon cycle that could not be directly measured within the Trout Beck catchment is $\mathrm{CH}_{4}$. A common approach to the consideration of $\mathrm{CH}_{4}$ flux is to consider its relation to potential drivers especially depth to the water table (Roulet et al., 1993; Daulet and Clymo, 1998; Hargreaves and Fowler, 1998). Reed and Mitchell (pers comm) in a review of $\mathrm{CH}_{4}$ flux measurements for peat found a statistically significant relationship between $\mathrm{CH}_{4}$ flux with water table depth for all temperatures when averaging over day and night measurements:

$\ln F=4.12-3.9 W_{D}$

where: $F=$ the molar flux of $\mathrm{CH}_{4}\left(\mu \mathrm{mol} \mathrm{CH} 4 / \mathrm{m}^{2} / \mathrm{h}\right)$; and $W_{\mathrm{D}}=$ depth to the water table $(\mathrm{m})$. Water table depths have been recorded for the site only since October 1994 and so in order to complete the budgets to the beginning of 1993 the monthly average depth to the water table was calculated from the catchment water balance using the method of Worrall et al. (2004).

\subsection{Carbon budget}

Given this approach the total magnitude of the carbon sink would be:

$F_{C}=\mathrm{PP}+R+\mathrm{POC}+\mathrm{DOC}+\operatorname{dissCO} \mathrm{CO}_{2}+\mathrm{CH}_{4}$

Where: $F_{\mathrm{c}}=$ the total flux of the catchment $\left(\mathrm{Mg} \mathrm{C} / \mathrm{km}^{2} / \mathrm{yr}\right)$; $\mathrm{POC}=$ the annual flux of $\mathrm{POC}\left(\mathrm{Mg} \mathrm{C} / \mathrm{km}^{2} / \mathrm{yr}\right) ; \mathrm{DOC}=$ annual DOC flux $\left(\mathrm{Mg} \mathrm{C} / \mathrm{km}^{2} / \mathrm{yr}\right)$; diss. $\mathrm{CO}_{2}=$ the annual flux of excess dissolved $\mathrm{CO}_{2}$ $\left(\mathrm{Mg} \mathrm{C} / \mathrm{km}^{2} / \mathrm{yr}\right)$; and $\mathrm{CH}_{4}=$ the annual methane flux $\left(\mathrm{Mg} \mathrm{C} / \mathrm{km}^{2} / \mathrm{yr}\right)$. If the DOC flux is taken as that leaving the peat profile based upon the soil DOC concentrations then it is not necessary to include rainfall DOC, (although it is calculated in the study). The overall flux is calculated for the combination of uptake and release pathways given the preferred method and by convention a negative flux is considered as uptake of carbon by the system. This includes both fluvial and gaseous uptakes and releases and as such this is an estimate for the peat soils of a whole catchment rather than just for a peat profile or the whole catchment.

\subsection{Error estimation}

In all budget calculations there are a number of sources of error. Within interpolation methods the major sources of error are the sampling frequency and the inherent error in the method used. Worrall and Burt (2007) have used a sub-daily time series of DOC concentration and systematically degraded the time series to assess the error upon decreasing sampling frequency. By going from subdaily to weekly sampling the standard error was $\pm 8 \%$. Each method used for flux estimate has an inherent error: Harrison et al. (1990) give a formula for calculating the inherent error in method 5: in this case, $\pm 3 \%$, therefore the error in weekly sampling for an interpolation method is $\pm 11 \%$.

For those flux estimates based upon extrapolation methods, the error is in the fit of the equation used. For each equation used the standard error of the equation's coefficients and constants were calculated and from there an upper and lower limit upon the flux of POC, net ecosystem respiration of $\mathrm{CO}_{2}$; uptake of $\mathrm{CO}_{2}$ by primary productivity and $\mathrm{CH}_{4}$ were estimated.

Error in the rainfall flux estimate would be expected to be relatively small as the DOC analysis was performed upon composite samples rather than spot samples as with the fluvial DOC, therefore the significant source of error would only occur if DOC degraded within the samples between falling in the rain and analysis and/or if the rainfall as recorded at the gauge was not representative of the catchment.

The error in the total carbon budget is firstly assessed by combining all the possible methods for all the uptake and release pathways to show the variation due to method of estimation. Secondly, the effect of the error in each method on the total carbon flux is assessed by the combination of the errors of each of the uptake and release pathways included in Eq. (6): 100 values were chosen at random from this range and combined in Eq. (6). The resulting distribution of carbon budgets was then examined to give the standard error of the budget estimate.

\section{Results}

\subsection{Net ecosystem respiration of $\mathrm{CO}_{2}$}

Based upon Eq. (2) the net ecosystem respiration of $\mathrm{CO}_{2}$ varies from 49.1 to $58.2 \mathrm{Mg} \mathrm{C} / \mathrm{km}^{2} / \mathrm{yr}$ with a standard error of $\pm 7.7 \%$ (Fig. 2). 


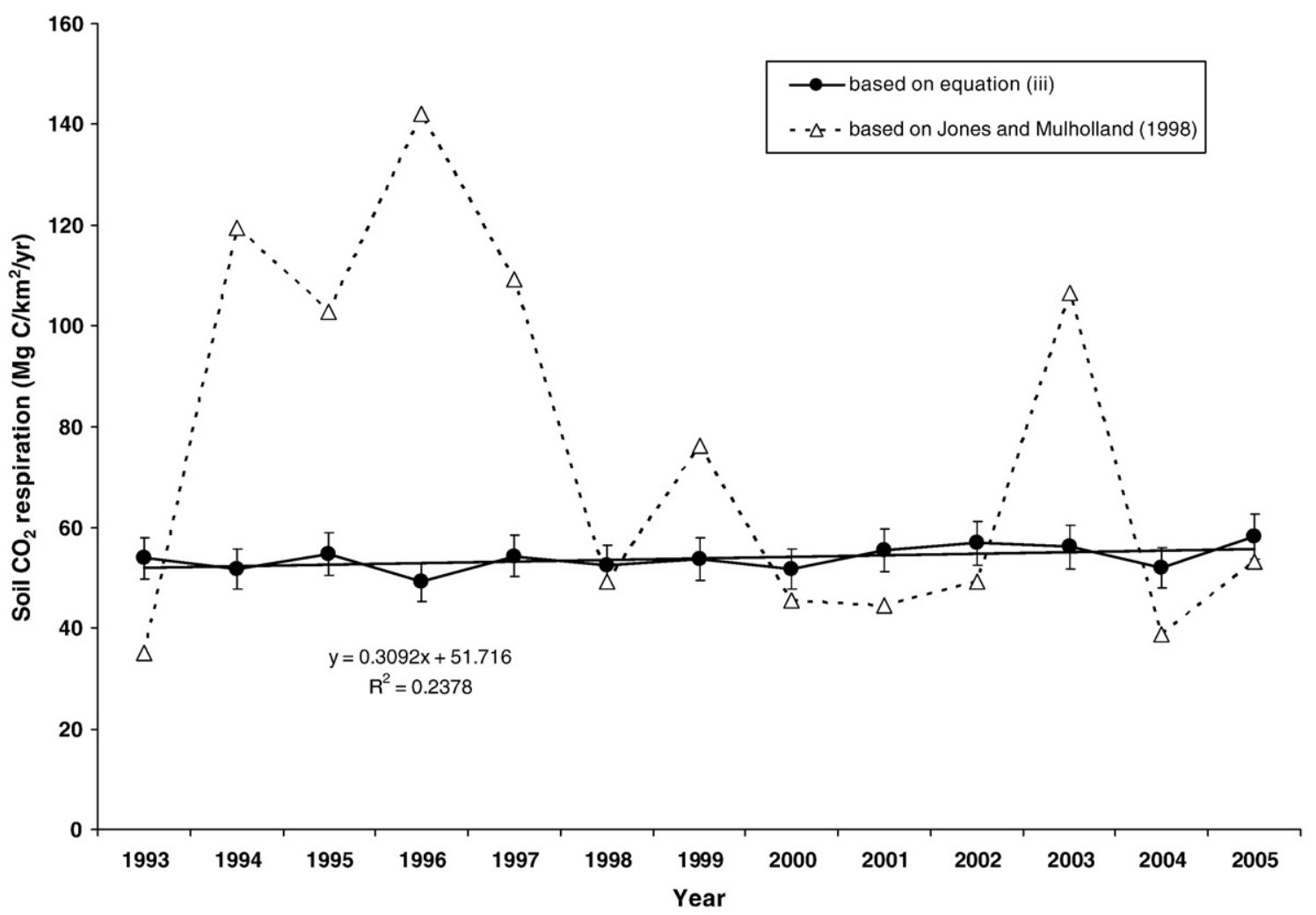

Fig. 2. Annual soil $\mathrm{CO}_{2}$ respiration flux as estimated based upon Eq. (2) and the approach of Jones and Mulholland (1998) over the period $1993-2005$.

The lowest value of net ecosystem respiration was in 1996. The variation in the net ecosystem respiration of $\mathrm{CO}_{2}$ is limited because it is taken as being controlled by soil temperature and water table depth and these vary little between years. Net ecosystem respiration of $\mathrm{CO}_{2}$ should increase with increasing air temperatures but also with increasing depth to the water table via increased evaporation. The results of extrapolation show that there is a significant upward trend $(P<0.05, n=13-$ Fig. 2$)$ on this net ecosystem respiration record with a $0.7 \%$ annual increase or a $9.1 \%$ increase over the period of the record.

In comparison, the net ecosystem respiration calculated from dissolved $\mathrm{CO}_{2}$ (Jones and Mulholland, 1998) shows a far higher degree of variation (Fig. 2), with variation between 35 and $142 \mathrm{Mg} \mathrm{C} / \mathrm{km}^{2} / \mathrm{yr}$. In all cases the predicted net ecosystem respiration is outside the error band estimated above, however, the annual results based upon the dissolved $\mathrm{CO}_{2}$ are fairly evenly distributed about the values predicted using Eq. (2) above, 6 out of 13 are larger and 7 smaller in magnitude. Therefore, the comparison suggests that values calculated on the basis of soil temperature and water table depth are of the correct order of magnitude but may underestimate the net ecosystem respiration during drought years.

\section{2. $D O C$}

The DOC flux at the outlet of the Trout Beck stream varied from 10.3 to $25.2 \mathrm{MgC} / \mathrm{km}^{2}$ with the values showing a change across the severe drought of 1995, which in this catchment was approximately 1 in 33 drought (Fig. 3, Worrall et al., 2006b). If the shallow soil water composition is considered as the source water, and the DOC concentration lost from the peat soils of the catchment varies from 12.5 to $85.9 \mathrm{Mg} \mathrm{C} / \mathrm{km}^{2} / \mathrm{yr}$, with an error of $\pm 12 \%$ (Fig. 3), i.e. a percentage loss of DOC across the catchment varied from 23 to $76 \%$. Plotting the DOC flux based on soil concentrations and Trout Beck concentrations shows that the comparison is best described by a linear relationship i.e. the loss of DOC in the system is best described by a fixed fraction rather than increasing or decreasing with DOC flux (Fig. 4). However, the relationship in Fig. 4 implies that there would be flux of DOC from the catchment even at zero flux from the soil. This could imply an additional source of DOC from the catchment that is always present. One possibility is a flux of DOC from deeper layers in the peat not assessed in the monitoring for this study. The fate of this lost DOC is uncertain, however it may not be that this carbon is simply lost to the atmosphere as $\mathrm{CO}_{2}$ but it is possible that this carbon is lost to adsorption and/or flocculation processes rather than biodegradation or photo-oxidation.

In a review of annual DOC flux from a range of catchments Hope et al. (1997) document values up to $10.3 \mathrm{MgC} / \mathrm{km}^{2} / \mathrm{yr}$ (River Halladale, Sutherland, Scotland). Dawson et al. (2004) report DOC exports for a range of small, upland peat catchments, with values ranging from 8.3 to $26.2 \mathrm{Mg} \mathrm{C} / \mathrm{km}^{2} / \mathrm{yr}$ in catchments between 0.41 and $46.3 \mathrm{~km}^{2}$, with the higher exports being reported in the smaller catchments. These studies do not allow for in-stream loss and so compare favourably with the values of DOC export measured at the Trout Beck outlet of 10 to $25 \mathrm{MgC} / \mathrm{km}^{2} / \mathrm{yr}$. but would not be expected to compare to the flux assessed from soil DOC concentrations.

\section{3. $P O C$}

The annual POC flux from the whole catchment measured in this study varies from $7-22.4 \mathrm{MgC} / \mathrm{km}^{2} / \mathrm{yr}$. Based upon the fit of the rating curve the variation in this estimate is $\pm 86 \%$. The reason for this large uncertainty is that the fit of the rating curve is a significant fit but there is considerable scatter in the data. Evans et al. (2006) report values of POC export from a peat-covered catchment, assuming an organic carbon content of organic matter as $50 \%$, are as high as $185.9 \mathrm{Mg} \mathrm{C} /$ $\mathrm{km}^{2} / \mathrm{yr}$ for a small upland peat catchment in the southern Pennines. However, lower values have been measured for mid-Wales (2.7 MgC/ $\mathrm{km}^{2} / \mathrm{yr}$ - Dawson et al., 2002), NE Scotland (1.9 MgC/ $\left.\mathrm{km}^{2} / \mathrm{yr}\right)$, and as low as $0.12 \mathrm{MgC} / \mathrm{km}^{2} / \mathrm{yr}$ for a partially peat-covered catchment (64\% peat cover) in northern Scotland (Dawson et al., 1995). However, it 


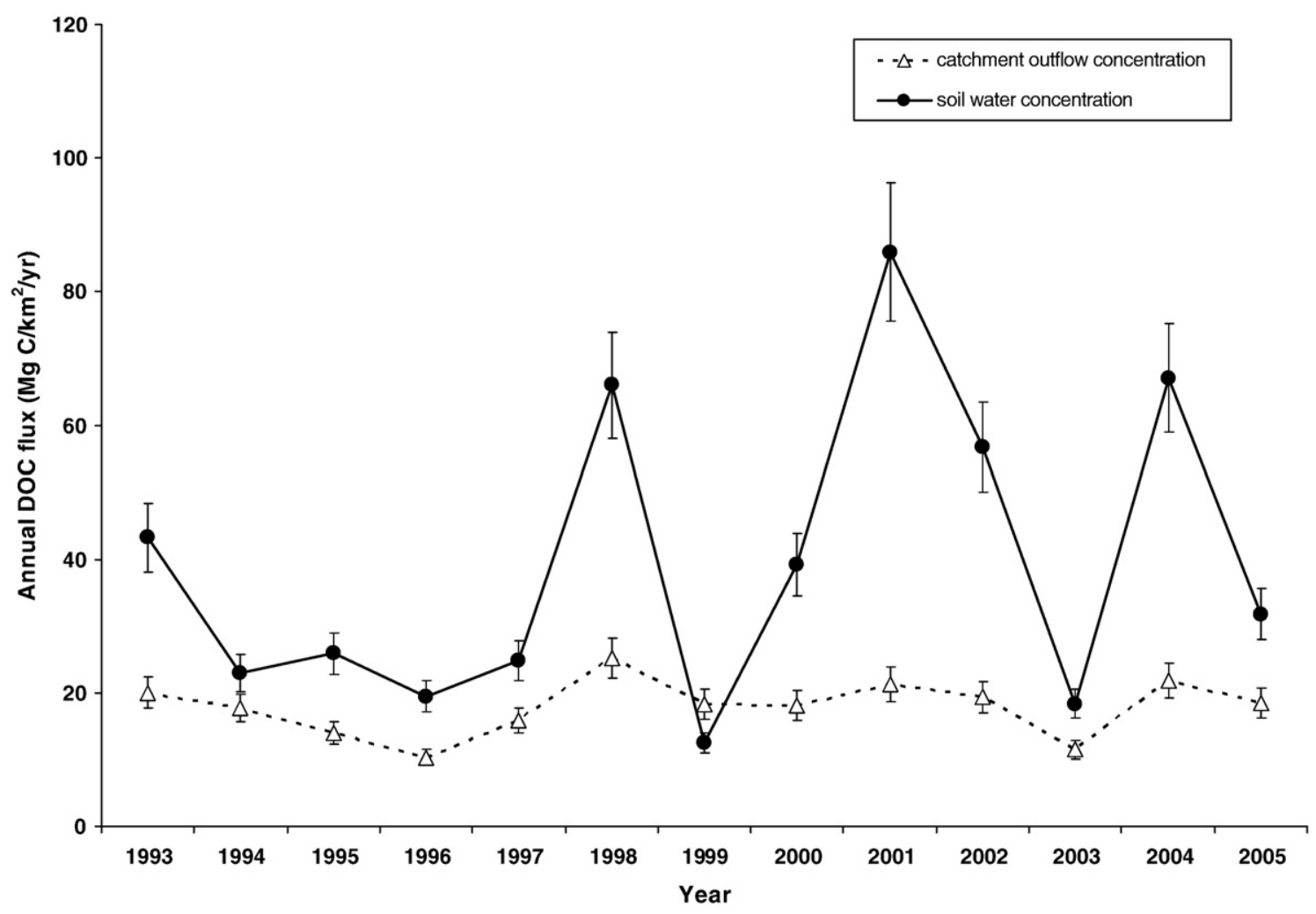

Fig. 3. Annual DOC flux based upon soil water concentrations and the flux at the catchment outlet over the period 1993-2005.

should be noted that flux estimates given here are from the whole catchment and not the flux of POC from the peat soils of the catchment. It would be expected that the POC flux leaving the peat soils of the catchment would be higher than that measured at the catchment outlet.

\subsection{Dissolved $\mathrm{CO}_{2}$}

The value of dissolved $\mathrm{CO}_{2}$ at emergence from the peat soils of the catchment varied from 1.0 to $15.2 \mathrm{Mg} \mathrm{C} / \mathrm{km}^{2} / \mathrm{yr}$ with a standard error of $\pm 12 \%$. Values reported in the literature for peatland catchments

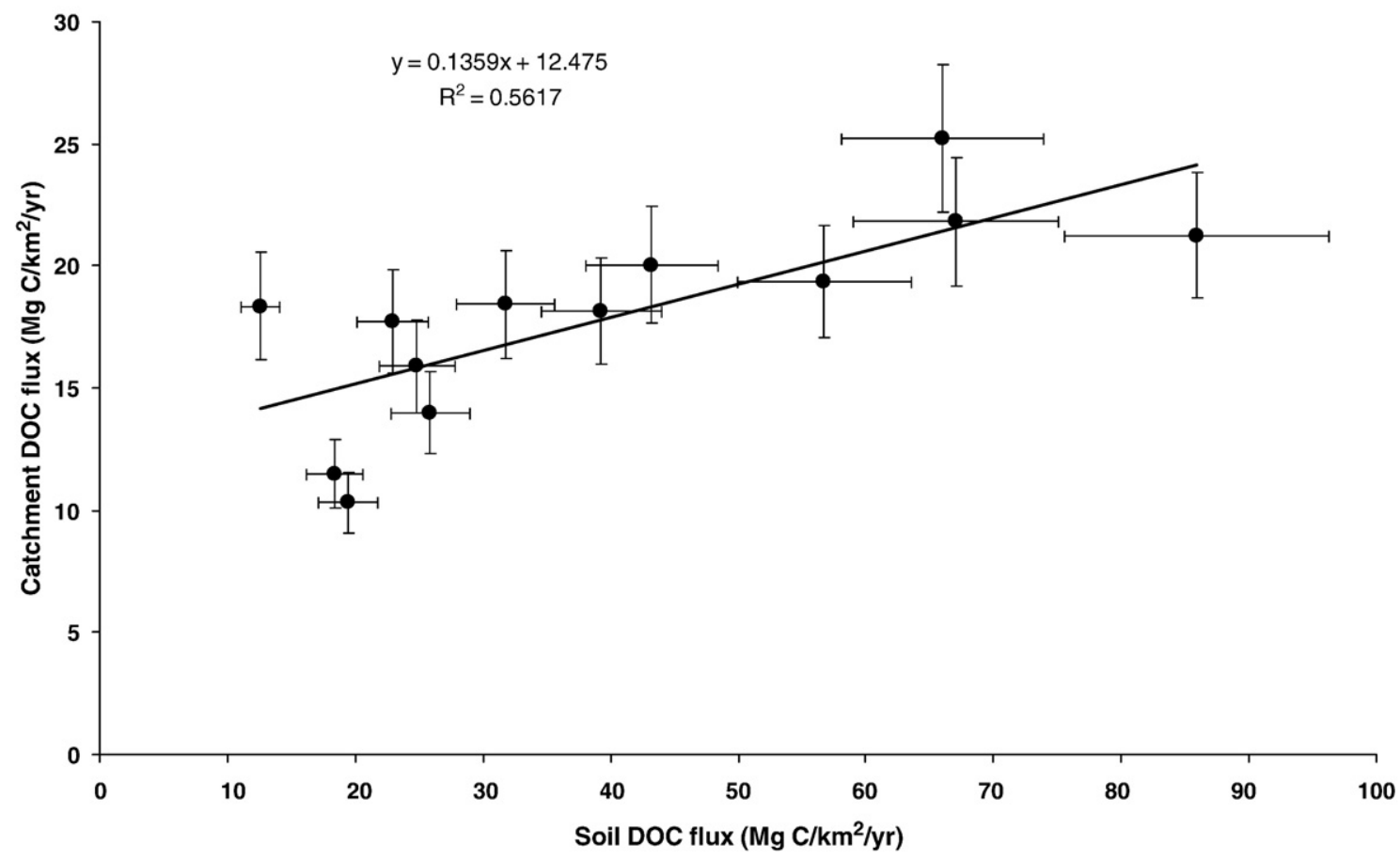

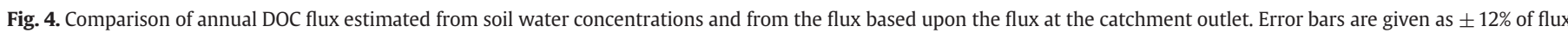
value. 
vary from as low 0.2 to $1.1 \mathrm{Mg} \mathrm{C} / \mathrm{km}^{2} / \mathrm{yr}$ (Dawson et al., 2004); however, these are values uncorrected for losses within the streams of the catchment and so do not represent values of dissolved $\mathrm{CO}_{2}$ at emergence from the peat soils of the catchment. The highest values reported by Dawson et al. (2004) were for the smallest catchments in their study, i.e. where the influence of in-stream processes were at the minimum relative to the other catchments in their study.

\subsection{Rainfall DOC}

The rainfall DOC is not required in the budget if the loss within the stream is accounted for, however, inputs of DOC from rain varied from -0.4 to $-4.2 \mathrm{Mg} \mathrm{C} / \mathrm{km}^{2} / \mathrm{yr}$. Willey et al. (2000) estimated that global precipitation input of DOC was $0.4 \times 10^{9} \mathrm{Mg} \mathrm{C} / \mathrm{yr}$, of which $70 \%$ fell on land, which is an average input to land of $-1.88 \mathrm{Mg} \mathrm{C} / \mathrm{km}^{2} / \mathrm{yr}$.

\subsection{Primary productivity}

When the primary productivity is estimated from Eq. (3), the values are between -151 and $-190 \mathrm{Mg} \mathrm{C} / \mathrm{km}^{2} / \mathrm{yr}$ and when estimated from actual evaporation the range is between -33 and $-293 \mathrm{Mg} \mathrm{C} / \mathrm{km}^{2} / \mathrm{yr}$ (Fig. 5). Based on Eq. (4), Garnett (1998) proposed values of primary productivity of between 117 and $341 \mathrm{Mg} \mathrm{C} /$ $\mathrm{km}^{2} / \mathrm{yr}$. Values calculated based upon radiation are far less variable because there is little variation in light conditions between years but there can be wide variation between years in the amount of actual evaporation. In comparison, the primary productivity based upon actual evaporation peaks in the drought years between 1995 and 1997 (Fig. 5), but there is also a peak in 1998 which was one of the wettest years in the study period but nevertheless experienced high actual evaporation. A detailed examination of the 1998 meteorological and hydrological shows that the large estimated AET in 1998 is due to a large snowfall in late November that does not translate in that year into an increased flow, hence, when AET is calculated from a water budget approach this snowfall appears as evaporation. This would suggest that, although this latter technique is easily applied refinements to the methods are required.

\subsection{Methane}

The value of the $\mathrm{CH}_{4}$ flux varied from 5.2 to $6.9 \mathrm{Mg} \mathrm{C} / \mathrm{km}^{2} / \mathrm{yr}$ with a standard error of $80 \%$ - the large error seems appropriate for the one component not measured within the catchment. There are a few comparative studies in the UK that report annual budgets as opposed to partial studies. However, Macdonald et al. (1998) found $\mathrm{CH}_{4}$ fluxes for a blanket bog in Scotland between $0.16-13.5 \mathrm{Mg} \mathrm{C} / \mathrm{km}^{2} / \mathrm{yr}$. For Tundra peat, Nakano et al. (2000) found values as high as $76.7 \mathrm{MgC} /$ $\mathrm{km}^{2} / \mathrm{yr}$. For lowland peat in the Netherlands, Best and Jacobs (1997) found a methane production rate of $2 \mathrm{MgC} / \mathrm{km}^{2} / \mathrm{yr}$, while Van den Pol-Van Dasselaar et al. (1999), also for lowland Dutch peat, found methane flux values ranging from $2.3-28 \mathrm{MgC} / \mathrm{km}^{2} / \mathrm{yr}$. Some boreal bogs are actually net methanotrophic with bogs acting as net sinks of $\mathrm{CH}_{4}$ of up to $0.24 \mathrm{Mg} \mathrm{C} / \mathrm{km}^{2} / \mathrm{yr}$.

\subsection{Carbon budget}

Given the above discussion of the alternative methods of calculating the main carbon fluxes our preferred combination of techniques include: primary productivity measured from Eq. (3); and net ecosystem respiration of $\mathrm{CO}_{2}$ from Eq. (2). The preferred measures of carbon uptake and release pathways measured and estimated in this study show that the catchment was always a net sink of carbon over the entire study period varying between -20 and $-91 \mathrm{Mg} \mathrm{C} /$ $\mathrm{km}^{2} / \mathrm{yr}$, with an average of $-56 \mathrm{Mg} \mathrm{C} / \mathrm{km}^{2} / \mathrm{yr}$ (Fig. 6) (Table 1). However, when other possible combinations of estimation techniques other than the preferred combination also indicate a reduction in the size of the sink or it would seem that the catchment could be a net source of carbon. The error based upon the combination of the standard errors of the individual components is $\pm 12 \%$. When only direct exchange with the atmosphere is considered, then the

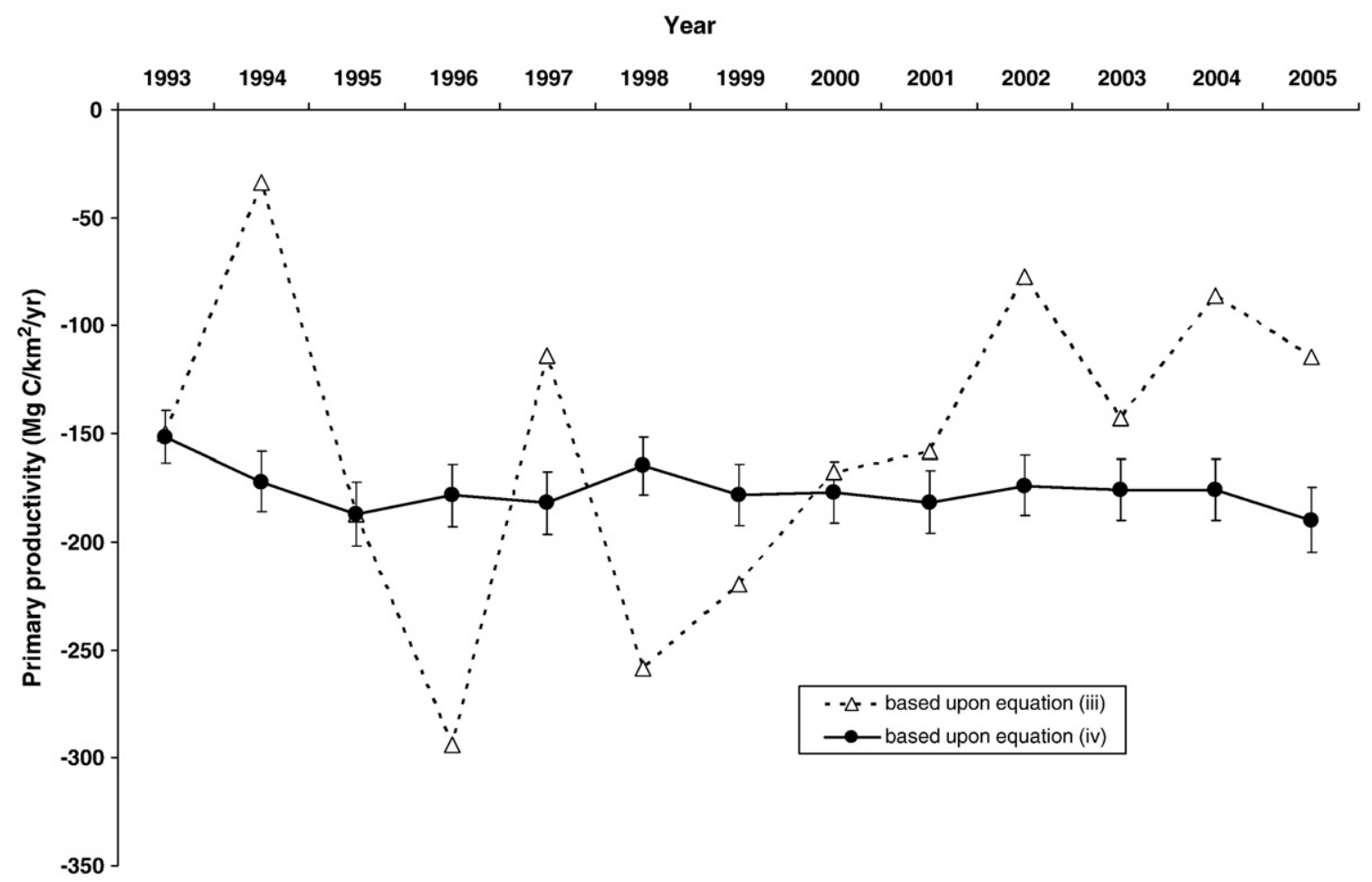

Fig. 5. Annual primary productivity 1993 to 2005 based upon Eqs. (3) and (4). 


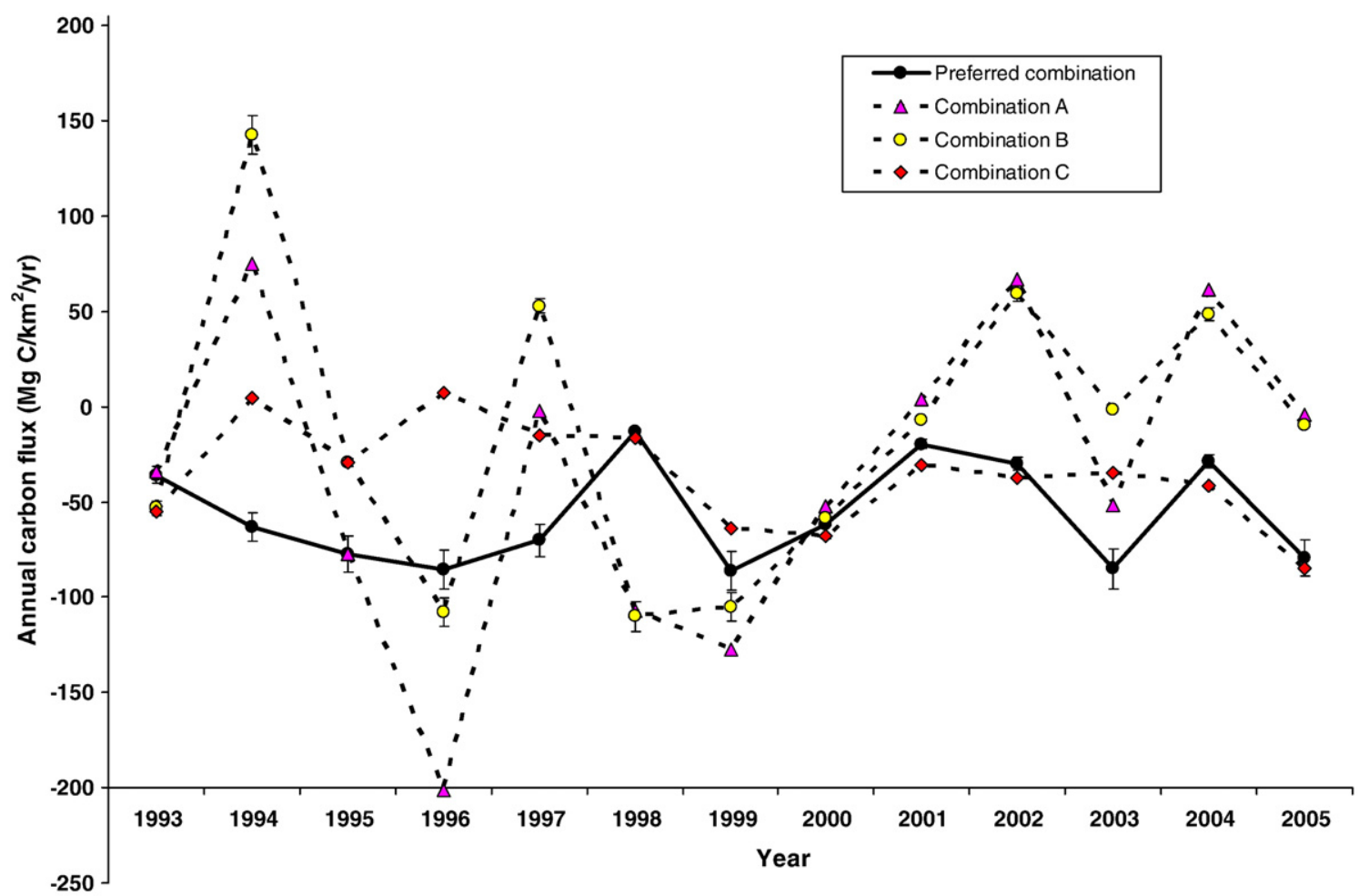

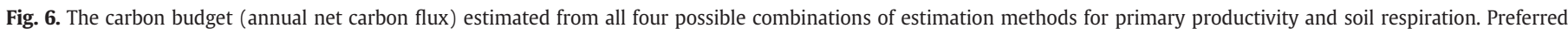

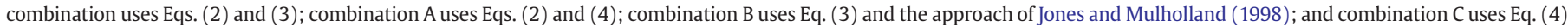
and the approach of Jones and Mulholland (1998).

catchment is a net sink of between 53 and $119 \mathrm{Mg} \mathrm{C} / \mathrm{km}^{2} / \mathrm{yr}$. However this latter calculation is with respect to processes operating within the Trout Beck catchment and it would be reasonable to assume that further biodegradation of DOC and POC occurs after leaving the catchment.

The stoichiometry of the reactions of carbon in the catchment can be estimated if the average flux for each component is normalised to the average annual uptake via primary productivity, then:

$100 C_{\mathrm{pp}} \Rightarrow 35 C_{R}+26 C_{\mathrm{DOC}}+4 C_{\mathrm{CH} 4}+4 C_{\mathrm{dissco} 2}+31 C_{\mathrm{RES}}$

where $C_{\mathrm{x}}=$ carbon from the following uptake or release pathways, where $x$ is: $\mathrm{pp}=$ primary productivity, $R=$ net ecosystem respiration, $\mathrm{DOC}=$ dissolved organic carbon; $\mathrm{CH} 4=$ methane; dissco $_{2}=$ dissolved

Table 1

Summary of the range of each carbon uptake and release pathway from across the entire study period with their estimated percentage standard error.

\begin{tabular}{|c|c|c|c|c|}
\hline \multirow[t]{2}{*}{ Pathway } & \multirow[t]{2}{*}{ Method } & \multicolumn{2}{|l|}{ Range } & \multirow{2}{*}{$\frac{\text { Error }}{(\%)}$} \\
\hline & & Minimum & Maximum & \\
\hline \multirow{2}{*}{$\begin{array}{l}\text { Primary } \\
\text { productivity }\end{array}$} & PAR (Eq. (3)) & -151.4 & -189.1 & \\
\hline & AET (Eq. (4)) & 33.9 & 258.5 & \\
\hline \multirow[t]{2}{*}{ Soil respiration } & Eq. (7) & 49.1 & 58.2 & 7.7 \\
\hline & Jones and Mulholland (1998) & 34.9 & 119.8 & \\
\hline Methane & & 5.6 & 6.9 & 80 \\
\hline Dissolved $\mathrm{CO}_{2}$ & & 1.0 & 15.1 & 12 \\
\hline \multirow{2}{*}{$\begin{array}{l}\text { Dissolved organic } \\
\text { carbon (DOC) }\end{array}$} & Flux at catchment outlet & 10.3 & 21.8 & 12 \\
\hline & $\begin{array}{l}\text { Flux based on soil water } \\
\text { concentration }\end{array}$ & 12.5 & 85.9 & 12 \\
\hline $\begin{array}{l}\text { Particulate organic } \\
\text { carbon (POC) }\end{array}$ & & 7.0 & 22.4 & 86 \\
\hline Rain DOC & & 0.5 & 4.2 & - \\
\hline Total & & -20 & -91 & \\
\hline
\end{tabular}

$\mathrm{CO}_{2}$; and $\mathrm{RES}=$ residual carbon stored in the soil. At this scale, input from rainfall is negligible. Further, POC losses are not included in this equation as POC losses are from the residual carbon stored in the soil and so a further equation can be given:

$31 C_{\text {res }} \Rightarrow 9 C_{\mathrm{POC}}+22 C_{\mathrm{RES}}$

where: $C_{\mathrm{POC}}=$ the carbon lost as particulate organic carbon. A schematic representation of the estimated carbon budget for the Trout Beck catchment is given in Fig. 7.

\section{Discussion}

An important question is how does the value of carbon flux calculated here relate to other values for similar peatlands? Firstly, this result cannot be easily compared to other flux studies as they are all limited to a subset of carbon uptake and release pathways and do not define a complete budget. However, several long-term accumulation studies have been performed at this field site. Garnett et al. (2000) estimated peat accumulation since 1954 using an SCP method in a number of plots in the study catchment. Recalculation of their data provides estimates of average accumulation on the three different moorland land management plots of: $71 \mathrm{Mg} \mathrm{C} / \mathrm{km}^{2} / \mathrm{yr}$ (grazed and rotationally burnt every $10 \mathrm{yr}$ ); $18 \mathrm{Mg} \mathrm{C} / \mathrm{km}^{2} / \mathrm{yr}$ (ungrazed, unburnt); and $126 \mathrm{Mg} \mathrm{C} / \mathrm{km}^{2} / \mathrm{yr}$ (grazed and unburnt), with a standard error on each estimate of $\pm 11 \mathrm{Mg} \mathrm{C} / \mathrm{km}^{2} / \mathrm{yr}$. This is at the upper end of estimates presented in this study, however, given the historical evidence of peat erosion in the catchment during this period (Evans and Warburton, 2005) this direct comparison is hard to justify because peat accumulation would be expected to vary with position in the catchment. Furthermore, studies of peat accumulation occur mainly on interfluves while peat erosion is concentrated in the vicinity of streams and peat accumulation rates would underestimate the losses due to POC fluxes. 


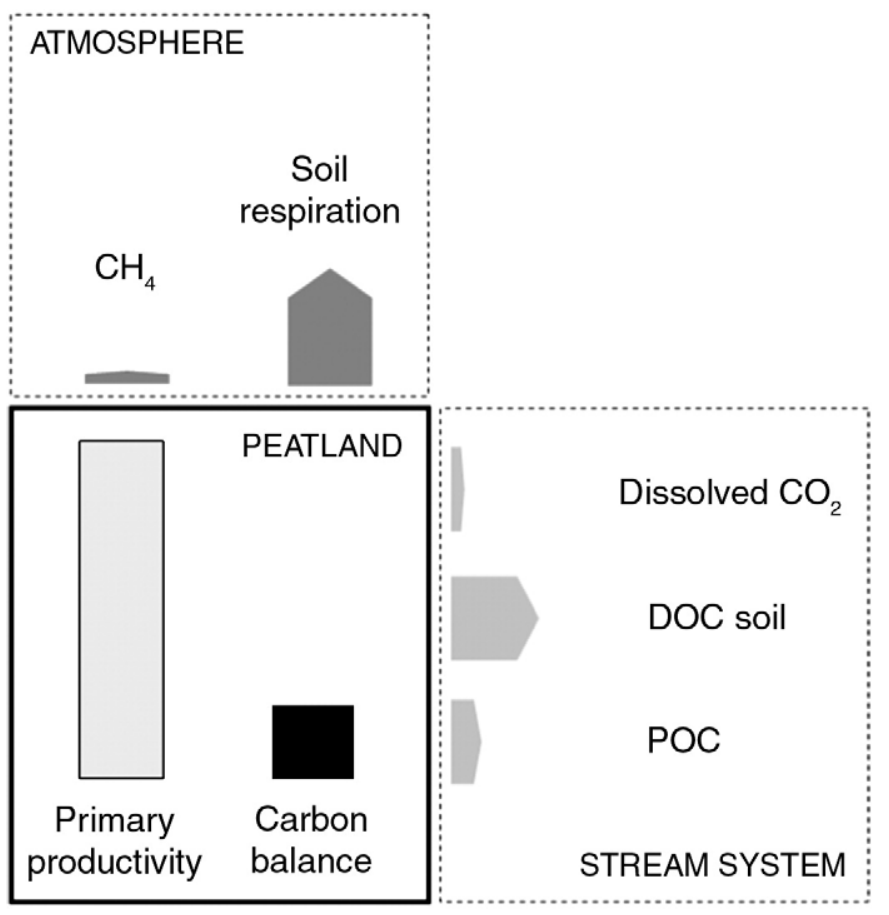

Fig. 7. A schematic representation of the amount and pathways of carbon loss and uptake from the study site.

The $C$ flux estimated by this study varied from -20 and $-91 \mathrm{Mg}$ $\mathrm{C} / \mathrm{km}^{2} / \mathrm{yr}$, is there any indication what is driving this inter-annual variation? The largest sink carbon sinks occurred in 1996, 1999 and 2003 and the smallest occurred in 1998, 2001, 2002 and 2004. The difference between these two sets of years is that the larger sinks are in the relative dry years and the smaller in the wetter years. The reason for this is possible to explain in terms of the fluvial fluxes, i.e. a wetter year gives rise to higher fluvial flux through the catchment increasing losses of DOC, POC and dissolved $\mathrm{CO}_{2}$. It might well be expected that there would be certain seasons or months when changes in rain and runoff would have particularly marked effects. For example, DOC concentrations in soil water are particularly high in the summer months (June-August) but in this catchment DOC flux tends to peak in the Autumn when the runoff begins to increase after a summer minimum. If there were more runoff events in the summer when available DOC concentration is relatively high then the increase in annual flux might be more marked.

It is interesting to speculate on how these flux estimates can be applied at a larger scale. There is a range of estimates of the total peat resource within the UK. Milne and Brown (1997) gave the area of blanket peat in Scotland to be $25,641 \mathrm{~km}^{2}$ and the area of raw peat soils in England and Wales as $3568 \mathrm{~km}^{2}$, giving 29,209 $\mathrm{km}^{2}$ in total. Cannell et al. (1993) estimated the area of deep peats as $19,224 \mathrm{~km}^{2}$. The ITE Countryside Survey (Haines-Young et al., 2000) gives the area of "bog" to be $23,600 \mathrm{~km}^{2}$. The lowest estimate of area of blanket mire is $14,790 \mathrm{~km}^{2}$ (Tallis and Meade, 1998). Given this variability and in order to determine a representative value of the UK peat carbon budget, estimates of the area of UK peat were selected randomly from the range of 14,790 to $29,209 \mathrm{~km}^{2}$ and combined with a randomly selected value of annual carbon budget from the range of carbon budget estimated in this study $\left(20-91 \mathrm{Mg} \mathrm{C} / \mathrm{km}^{2} / \mathrm{yr}\right)$. This is repeated for 100 random selections resulting in an estimate of the carbon budget for UK peat of $1.2 \mathrm{Tg} \mathrm{C} / \mathrm{yr}$ with a standard deviation of $0.44 \mathrm{Tg} \mathrm{C} / \mathrm{yr}$. This is a larger estimate than that given by Worrall et al. (2003a) $(0.15-0.29 \mathrm{Tg}$ $\mathrm{C} / \mathrm{yr}$ ) and that given by Cannell et al. (1993) (0.7 Tg C/yr), even though the budget given here in this study included a range of loss pathways not included in the latter study. However, even $1.2 \mathrm{Tg} C / \mathrm{yr}$ is less than
$1 \%$ of UK fossil fuel emissions (UK greenhouse gas inventory $2002=150.26$ Tg C - Baggott et al., 2004).

\section{Conclusions}

This study documents the most comprehensive carbon budget for a peat-covered catchment thus far completed. The principal findings show that:

i) Over a 13 year period the total carbon flux varies between -20 and $-91 \mathrm{Mg} \mathrm{C} / \mathrm{km}^{2} / \mathrm{yr}$.

ii) By far the biggest single component of the budget is the uptake of carbon by primary productivity (average across the study period of $176 \mathrm{MgC} / \mathrm{km}^{2} / \mathrm{yr}$ ).

iii) The next largest components are the loss of DOC from the soil water with on average of $39.5 \mathrm{Mg} \mathrm{C} / \mathrm{km}^{2} / \mathrm{yr}$ and net ecosystem respiration of $53.9 \mathrm{Mg} \mathrm{C} / \mathrm{km}^{2} / \mathrm{yr}$.

iv) The study focuses upon total carbon loss but also suggests that with respect to direct exchanges with the atmosphere would average $89 \mathrm{Mg} \mathrm{C} / \mathrm{km}^{2} / \mathrm{yr}$ within the confines of the catchment.

Given the ranges calculated in this study the carbon budget of UK peats would be $1.2 \mathrm{TgC} / \mathrm{yr} \pm 0.4 \mathrm{PgC} / \mathrm{yr}$, this is larger than the presently published values.

\section{Acknowledgements}

The authors are grateful for the ongoing support of the ECN staff and J.G. Rowson was supported by an NERC studentship.

\section{References}

Adamson JK, Scott WA, Rowland AP, Beard GR. Ionic concentrations in a blanket peat bog in northern England and correlations with deposition and climate variables. Eur J Soil Sci 2001;52:69-80.

Aerts R, Wallen B, Malmer N. Growth limiting nutrients in sphagnum-dominated bogs subject to low and high atmospheric nitrogen supply. J Ecol 1992;80:131-40.

Alm J, Schulman L, Walden J, Nykanen H, Martikainen PJ, Silvola J. Carbon balance of a boreal bog during a year with an exceptional dry summer. Ecology 1999;80:161-74.

Baggott SL, Lelland A, Passant NP, Watterson J. Review of carbon emission factors in the UK Greenhouse gas inventory. Harwell, UK: Aea Technology; 2004. AEAT/ENV/R/ 2347.

Best EPH, Jacobs FHH. The influence of raised water table levels on carbon dioxide and methane production in ditch-dissected peat grasslands in the Netherlands. Ecol Eng 1997:8:129-44.

Bubier JL, Crill PM, Moore TR, Savage K, Varner RK. Seasonal patterns and controls on net ecosystem $\mathrm{CO}_{2}$ exchange in a boreal peatland complex. Glob Biogeochem Cycles 1998;12:703-14.

Bubier JL, Bhatria G, Moore TR, Roulet NT, Lafleur PM. Spatial and temporal variability in growing season net ecosystem carbon dioxide exchange at a large peatland in Ontario, Canada. Ecosystems 2003;6:353-67.

Burt TP, Adamson JK, Lane AMJ. Long-term rainfall and streamflow records for north central England: putting the environmental change network site at Moor House, Upper Teesdale, in context. Hydrol Sci J 1998;43:775-87.

Cannell MGR, Dewar RC, Pyatt DG. Conifer plantations on drained peatlands in Britain: a net gain or loss of carbon? Forestry 1993:66:353-69.

Christensen TR, Jonasson S, Michelson A, Callaghan TV, Haystrom M. Environmental controls on net ecosystem respiration in the Eurasian and Greenlandic Arctic. J Geophys Res - Atmospheres 1998;103:29015-21.

Clark JM, Chapman PJ, Adamson JK, Lane SJ. Influence of drought-induced acidification on the mobility of dissolved organic carbon in peat soils. Glob Chang Biol 2005; 11:791-809.

Clymo RS, Turunen J, Tolonen K. Carbon accumulation in peatland. Oikos 1998;81:368-88.

Cortufo MF, Gorissen A. Elevated $\mathrm{CO}_{2}$ enhances below ground $\mathrm{C}$ allocation in three perennial grass species at different levels of $\mathrm{N}$ availability. New Phytol 1997; 137:421-31.

Crisp DT, Howson G. Effect of air temperature upon mean water temperature in streams in the north Pennines and English Lake District. Freshw Biol 1982;12:359-67.

Dawson JJC, Hope D, Cresser MS, Billett MF. Downstream changes in free $\mathrm{CO}_{2}$ in an upland catchment in northeastern Scotland. J Environ Qual 1995;24:699-706.

Dawson JJC, Billet MF, Neal C, Hill S. A comparison of particulate, dissolved and gaseous carbon in two contrasting upland streams in the UK. J Hydrol 2002;257:226-46.

Dawson JJC, Billet MF, Hope D, Palmer SM, Deacon CM. Sources and sinks of aquatic carbon in a peatland stream continuum. Biogeochemistry 2004;70:71-92.

De Vries A, Klavers HC. Riverine fluxes of pollutants: monitoring strategies first, calcualtion methods second. Eur Wat Pollut Contrib 1994;4:12-7. 
Daulet WE, Clymo RS. Effects of temperature and water table on the efflux of methane from peatland surface cores. Atmos Environ 1998;32:3207-18.

Evans MG, Warburton J. Sediment budget for an eroding peat-moorland catchment in Northern England. Earth Surf Processes Landf 2005;30:557-77.

Evans MG, Burt TP, Holden J, Adamson JK. Runoff generation and water table fluctuations in blanket peat: evidence from UK data spanning the dry summer of 1995. J Hydrol 1999;221:141-60.

Evans CD, Montieth DT, Cooper DM. Long-term increases in surface water dissolved organic carbon: observations, possible causes and environmental impacts. Environ Pollut 2005;137:55-71.

Evans MG, Warburton J, Yang J. Eroding blanket peat catchments: global and local implications of upland organic sediment budgets. Geomorphology 2006;79:45-57.

Ferguson RI. River loads underestimated by rating curves. Water Resour Res 1986;22:74-6.

Freeman C, Ostle N, Kang H. An enzymic 'latch' on a global carbon store - a shortage of oxygen locks up carbon in peatlands by restraining a single enzyme. Nature 2001;409:149.

Frolking S, Roulet NT, Moore TR, Lafleur PM, Bubier JL, Crill PM. Modeling seasonal to annual carbon balance of Mer Bleue Bog, Ontario, Canada. Glob Biogeochem Cycles 2002;16(3) Art. No. 1030.

Funk DW, Pullman ER, Peterson KM, Crill PM, Billings WD. Influence of water table on carbon dioxide, carbon monoxide and methane fluxes from taiga bog microcosms. Glob Biogeochem Cycles 1994;8:271-8.

Garnett, M.H., PhD thesis, University of New Castle upon Tyne, (unpublished), 1998.

Garnett MH, Ineson P, Stevenson AC. Effects of burning and grazing on carbon sequestration in a Pennine blanket bog, UK. The Holocene 2000;10:729-36.

Glenn S, Heyes A, Moore TR. Carbon dioxide and methane emissions from drained peatland soils, southern Quebec. Glob Biogeochem Cycles 1993;7:247-58.

Gorham E. Northern peatlands: role in the carbon carbon cycle and probable responses to climate warming. Ecol Appl 1991;1:182-95.

Griffs TJ, Rouse WR, Waddington JM. Interannual variability of net ecosystem $\mathrm{CO} 2$ exchange at a subartic fen. Glob Biogeochem Cycles 2000;14:1109-21.

Haines-Young RH, Barr CJ, Black HIJ, Briggs DJ, Bunce RGH, Clarke RT, et al. Accounting for nature: assessing habitats in the UK countryside. London: HMSO; 2000.

Hargreaves KJ, Fowler D. Quantifying the effects of water table and soil temperature on the emission of methane from peat wetland at the field scale. Atmos Environ 1998;32:3275-82.

Harrison RM, Thorogood GA, Lacey RF. Comparison of load estimation from grab samples and flow proportional sampling. Medmenham, UK: Water Research Centre; 1990. Water Research Centre, report no. PRS 2383-M.

Heijmans MMPD, Berendse F, Arp WJ, Masselink AK, Klees H, de Visser W, et al. Effects of elevated carbon dioxide and increased nitrogen deposition on bog vegetation in the Netherlands. J Ecol 2001;89:268-79.

Hilbert DW, Roulet N, Moore TR. Modeling and analysis of peatlands as dynamical systems. J Ecol 2000;88:230-42.

Holden J. Recent reduction of frost in the North Pennines. J Meteorol 2001;28 (264):369-74

Hope D, Billett MF, Milne R, Brown TAW. Exports of organic carbon in British rivers. Hydrol Process 1997;11:325-44.

Hope D, Palmer SM, Billet MF, Dawson JC. Carbon dioxide and methane oxidation evasion from a temperate peatland stream. Limnol Oceanogr 2001;46:847-57.

Johnson, G.A.L., Dunham, K., The geology of Moor House. Nature Conservancy Council, HMSO, London, 1963.

Jones JB, Mulholland PJ. Carbon dioxide variation in a hardwood forest stream: an integrative measure of whole catchment soil respiration. Ecosystems 1998;1:183-96.

Kilian MR, van der Plicht J, van Geel B. Dating raised bog: new aspects of AMS C-14 wiggle matching, a reservoir effect and climatic change. Quat Sci Rev 1995;14:959-66.

Kilian MR, van Geel B, van der Plicht J. C-14 AMS wiggle matching of raised bog deposits and models of peat accumulation. Quat Sci Rev 2000;19:1011-33.

LaFleur PM, Roulet NT, Bubier JL, Frolking S, Moore TR. Interannual variability in the peatland-atmosphere carbon dioxide exchange at an ombogotrophic bog. Glob Biogeochem Cycles 2002;17(1036), doi:10,1029/2002GB001983.

Liss PS, Slater PG. Flux of gases across the air-sea interface. Nature 1974;247:181-4.

Littlewood IG. Hydrological regimes, sampling strategies, and assessment of errors in mass load estimates for United Kingdom rivers. Environ Int 1995;21:211-20.
Littlewood IG, Watts CD, Custance JM. Systematic application of United Kingdom river flow and quality databases for estimating annual river mass loads (1975-1994); 1998.

Lloyd CR. Annual carbon balance of a managed wetland meadow in the Somerset Levels, UK. Agric For Meteorol 2006;138(1-4):168-79.

Lloyd J, Taylor JA. On the temperature dependence of soil respiration. Funct Ecol 1994;8:315-23.

MacDonald JA, Fowler D, Hargreaves KJ, Skiba U, Leith ID, Murray MB. Methane emission rates from a northern wetland; response to temperature, water table and transport. Atmos Environ 1998;32:3219-27.

McKenzie C, Schiff S, Aravena R, Kelly C, Louis VS. Effect of temperature on production of $\mathrm{CH} 4$ and $\mathrm{CO} 2$ from peat in a natural and flooded boreal forest wetland. Clim Change 1998;40:247-66.

Milne R, Brown TA. Carbon in the vegetation and soils of Great Britain. J Environ Manag 1997:49:413-33.

Mitchell G, McDonald AT. Catchment characterisation as a tool for upland water management. J Environ Manag 1995;44(1):83-95.

Naden PS, McDonald AT. Statistical modelling of water colour in the uplands: the upper Nidd catchment 1979-1987. Environ Pollut 1989;60:141-63.

Nakano T, Kuniyoshi S, Fukuda M. Temporal variation in methane emission from tundra wetlands in a permafrost area, northeastern Siberia. Atmos Environ 2000;34:1205-13.

Neal C, House WA, Down K. An assessment of excess carbon dioxide partial pressure in natural waters based on $\mathrm{pH}$ and alkalinity measurements. Sci Total Environ 1998;210/211:173-85.

Roulet NT, Ash R, Quinton W, Moore TR. Methane flux from drained northern peatlands: effect of a persistent water table lowering on flux. Glob Biogeochem Cycles 1993;7:749-69.

Rowson, J.G., PhD thesis, University of Durham (unpublished), 2007.

Saarnio S, Jarvio S, Saarinen T, Vasander H, Silvola J. Minor changes in vegetation and carbon gas balance in a boreal mire under a raised $\mathrm{CO}_{2}$ or $\mathrm{NH}_{4} \mathrm{NO}_{3}$ supply. Ecosystems 2003;6(1):46-60.

Schlesinger $\mathrm{WH}$. Evidence from chronosequence studies for a low carbon storage potential of soils. Nature 1990;348:232-4.

Schimel DS. Terrestrial ecosystems and the carbon cycle. Glob Chang Biol 1995;1:77-91

Steudler PA, Bowden RD, Melillo JM, Aber JD. Influence of nitrogen fertilization on methane uptake in temperate forest soils. Nature 1989;341:314-6.

Sykes JM, Lane AMJ. The United Kingdom environmental change network: protocols for standard measurements of terrestrial sites. London: Natural Environment Research Council; 1996. p. 220.

Tallis JH, Meade R. Blanket mire degradation and management. In: Tallis JH, Meade R, Hulme PD, editors. Blanket mire degradation: causes, challenges and consequences. Aberdeen: Macauley Land Use Research Institute; 1998. p. 212-6.

Tolonen K, Turunen J. Accumulation rates of carbon in mires in Finland and implications for climate change. The Holocene 1996;6:171-8.

Turetsky MR, Manning SW, Wieder RK. Dating recent peat deposits. Wetlands 2004;24:324-56.

Van den Pol-Van Dasselaar A, Van Beusichem ML, Oenema O. Determinants of spatia variability of methane emissions from wet grasslands on peat soil. Biogeochemistry 1999;44:221-37.

Willey JD, Kieber RJ, Eyman MS, Yavitt JB. Rainwater dissolved organic carbon: concentrations and global flux. Glob Biogeochem Cycles 2000;14:139-48.

Worrall F, Burt TP. The flux of dissolved organic carbon from UK. Glob Biogeochem Cycles 2007;21(1) art. no. GB1013.

Worrall F, Reed M, Warburton J, Burt TP. Carbon budget for British upland peat catchment. Sci Total Environ 2003a;312:133-46.

Worrall F, Burt TP, Adamson JK. Controls on the chemistry of runoff from an upland peat catchment. Hydrol Process 2003b;17:2063-83.

Worrall F, Burt TP, Adamson JK. Can climate change explain increases in DOC flux from upland peat catchments? Sci Total Environ 2004;326:95-112.

Worrall F, Burt TP, Adamson JK. Fluxes of dissolved carbon dioxide and inorganic carbon from an upland peat catchment: implications for soil respiration. Biogeochemistry 2005;73:515-39.

Worrall F, Burt TP, Adamson JK. The rate of and controls upon DOC loss in a peat catchment. J Hydrol 2006a;321:311-25.

Worrall F, Burt TP, Adamson JK. Trends in drought frequency - the fate of Northern Peatlands. Clim Change 2006b;76:339-59. 